\title{
POPULATION STRUCTURE AND DENSITY OF Attalea phalerata MART. EX SPRENG. (ARECACEAE) IN A SEMIDECIDUOUS FOREST ${ }^{1}$
}

\author{
Aelton Biasi Giroldo², André R. Terra Nascimento ${ }^{3}$, Pedro Paulo Ferreira Silva e Gastão Viegas Pinho \\ Júnior ${ }^{4}$
}

\begin{abstract}
The structure of a population can be seen as the result of biotic and abiotic interacting forces. The studies of population characteristics are vital to improve the understanding of ecosystem functioning. In this study, we attempted to answer the two following questions: What are the population structure of Attalea phalerata? and Are there any influence of reproducers presence, canopy openness, declivity, basal area and soil coverage on recruitment of individuals in this population? We distinguished four ontogenetic stages in A. phalerata. Reproducers and virgins were sampled by using 25 plots $\left(400 \mathrm{~m}^{2}\right)$, juveniles and seedlings were sampled in sub-plots $\left(100 \mathrm{~m}^{2}\right)$. We found 2,328 Attalea phalerata individuals per hectare, first two ontogenetic stages accounted for $89.8 \%$ of the total, describing a relatively stable population. None of the analyzed factors were affecting the natural regeneration of Attalea phalerata in the fragment. The density and distribution pattern found for the population are probably signs of formation of oligarchic forests, moreover, the species seems to be able to colonize clearings and open areas.
\end{abstract}

Keywords: Canopy openness, Hemispherical photography and Population ecology.

\section{ESTRUTURA POPULACIONAL E DENSIDADE DE Attalea phalerata MART. EX SPRENG. (ARECACEAE) EM UMA FLORESTA SEMIDECIDUAL}

\begin{abstract}
RESUMO - A estrutura de uma população pode ser vista como o resultado da interação de forças bióticas e abióticas, sendo os estudos populacionais fundamentais para a compreensão do funcionamento dos ecossistemas. Neste trabalho, buscou-se responder a duas perguntas: Qual é a estrutura populacional de Attalea phalerata? Há alguma influência da presença de adultos, abertura do dossel, declividade, área basal e cobertura do solo sobre o recrutamento de novos indivíduos nessa população? Distinguiram-se quatro estágios ontogenéticos em A. phalerata. Adultos e pré-reprodutivos foram amostrados usando-se 25 parcelas $\left(400 \mathrm{~m}^{2}\right)$, sendo juvenis e plântulas amostrados em subparcelas $\left(100 \mathrm{~m}^{2}\right)$. Foram encontrados 2.328 indivíduos por hectare, e os dois primeiros estágios ontogenéticos representaram $89,8 \%$ do total, descrevendo uma população relativamente estável. Nenhum dos fatores analisados afetou a regeneração natural de Attalea phalerata no fragmento. A densidade e o padrão de distribuição encontrados na população constituíam, provavelmente, sinais de formação de florestas oligárquicas. Além disso, a espécie parece ser capaz de colonizar clareiras e áreas abertas.
\end{abstract}

Palavras-chave: Abertura de dossel, Ecologia de população and Fotografia hemisférica.

\footnotetext{
${ }^{1}$ Recebido em 26.09.2011 e aceito para publicação em 28.05.2012.

${ }^{2}$ Programa de Pós-Graduação em Ecologia pela Universidade de Brasília. Laboratório de Ecologia e Conservação, Embrapa Recursos Genéticos e Biotecnologia. E-mail: <aeltonbg@gmail.com>.

${ }^{3}$ Universidade Federal de Uberlândia, Instituto de Ciências Biomédicas, Instituto de Biologia. E-mail: <arnterra@ gmail.com>.

${ }^{4}$ Programa de Pós Graduação em Ecologia e Conservação de Recursos Naturais pela Universidade Federal de Uberlândia, Instituto de Ciências Biomédicas, Instituto de Biologia.
} 


\section{INTRODUCTION}

The demographic processes are the basis of spatial, age, and size structures of a population (SILVERTOWN; CHARLESWORTH, 2001). The structure of a population can be seen as the result of biotic and abiotic interacting forces, and in some cases, exposure suffered by predecessors in the past (HUTCHINGS, 1997). The individuals of a population can be characterized by their chronological age, which represent the period of time elapsed since their appearance until the present day, or by biological age, defined by morphological and physiological characteristics that determine the ontogenetic state (SMIRNOVA et al., 2002). The determination of ontogenetic stages may be more important than chronological age, because plants at different stages usually play different roles in a population (HUTCHINGS, 1997; SMIRNOVAet al., 2002). The studies of population characteristics are vital to improve the understanding of ecosystem functioning, since populations have properties that are unique, such as spatial distribution (ODUM; BARRETT, 2008).

The light conditions in the canopy forest can be estimated through several methods, such as hemispherical photographs (SATTLER et al., 2007, INOUE et al., 2004). Some advantages of hemispherical photography are the low cost and the versatility of the processing in the analysis, that increases the number of variables related to canopy (JONCKHEERE et al., 2004), and that, theoretically, could be used in any kind of canopy, including forests and savannas (RICH, 1990). The validity of the method is based on the principle of an ideal brightness value (pixels) as the threshold for distinguishing between the vegetation (canopy) and areas in the sky (JONCKHEERE et al., 2004). Thus, digital hemispherical photographs provide an alternative to calculate the leaf area index (LAI), the radiation balance and canopy opening (CO) (ZHANG, et al., 2005). The CO and the LAI are appropriate parameters and are often used to indirectly measure some biophysical factors that are essential to understand regeneration process in forest environments (ENGELBRECHT; HERZ 2001).

Several studies have shown that the distribution of palms can be affected by edaphic and topographic heterogeneity (SVENNING, 1999; CLARK et al., 1995; SVENNING, 2001), coverage at ground level and also the leaf litter that may affects the recruitment and survival

Revista Árvore, Viçosa-MG, v.36, n.4, p.637-645, 2012 of seeds and seedlings, affecting the adult population structure (CINTRA; TERBORGH, 2000). In this study, we attempted to answer two questions: 1- What are the population structure and the density of Attalea phalerata in the study area? 2- Are there any influence of the presence of reproducers, canopy openness, declivity, basal area and soil coverage on recruitment of individuals in this population?

\section{MATERIALAND METHODS}

\subsection{Study area and specie description}

This study was conducted in a anthropized semideciduous forest remnant linked to a gallery forest in the lower portions of the terrain. The fragment area is approximately 53.7 ha and it is located at $18^{\circ} 48^{\prime} 51^{\prime \prime} \mathrm{S}$, $48^{\circ} 9^{\prime} 54^{\prime \prime} \mathrm{W}$. The region climate is Aw megathermic with two defined seasons: dry season (from April to September) and rainy season (from October to March), according to Köppen classification. Attalea phalerata Mart. Ex Spreng. occurs in Planalto of Brazil and adjacent countries and in southern and western parts of the Amazon region of Peru, Brazil and Bolivia, in open areas, gallery forest, disturbed forest, forest islands in savanna, and occasionally lowland rain forest. The palm has solitary stems, in general shorts, $0-10 \mathrm{~m}$ tall, $0.25-0.60 \mathrm{~m}$ diameter. It has $11-30$ leaves, with sheath $0.7-1.7 \mathrm{~m}$ long and thin fibers on margins and rachis with 3.4 $-5.9 \mathrm{~m}$ long. Inflorescences interfoliar, with peduncle measured $0.6-1.2 \mathrm{~m}$ long. A. phalerata is known popularly with name bacuri and urucuri (HENDERSON et al., 1995).

\subsection{Data collection}

Data collection was conducted in August 2009, at the end of dry season. We distinguished four ontogenetic stages in A. phalerata, based on morphology and morphometric analyses, adapted from Souza et al. (2000): Seedlings had entire, distichous leaves, juveniles had bifid, incompletely segmented ones; pre reproductive or virgins produced completely segmented leaf blades, with size of reproduction, but do not show signs of previous reproduction and reproducers are recognized by the production of ûowers and fruits (Fig. 1).

Reproducers and virgins were sampled by using $2520 \times 20 \mathrm{~m}$ plots (each $400 \mathrm{~m}^{2}$ ), allocated along lines equidistant $10 \mathrm{~m}$, totaling 1 sampled hectare, juveniles 
and seedlings were sampled in sub-plots of $10 \times 10 \mathrm{~m}$ (each $100 \mathrm{~m}^{2}$ ) located within the 25 principal plots, totaling 0.25 sampled hectares. In each plot the following data were collected: number of individuals, total height and number of leaves. In addition, we collected seven bunches of distinct plants to account fruit production. We weighed and measured 140 fruits. We transversely sawed 25 fruits to count the number of seeds and 30 longitudinally to measure the seed and the endocarp.

We collected data of declivity, basal area, soil coverage, canopy openness (CO), in each plot. Declivity was measured with a clinometer, basal area was estimate with a Bitterlich's relascope, a measuring tape was

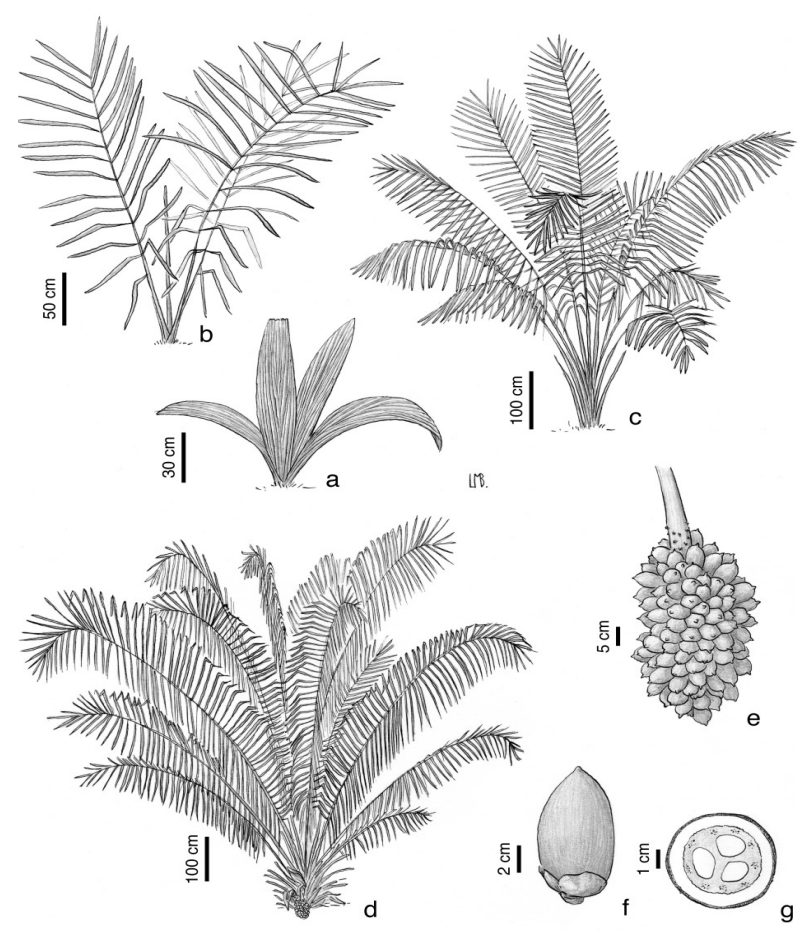

Figure 1 - Ontogenetic stages of Attalea phalerata Mart. ex Spreng. (a) Established seedling, (b) Juvenile, (c) Virgin, (d) Reproductive plant, (e) Mature infructescence, (f) Fruit, and (g) Transverse section of fruit.

Figura 1-Estágios ontogenéticos de Attalea phalerata Mart. ex Spreng. (a) Plântula, (b) Juvenil, (c) Virgem, (d) Adulto reprodutivo, (e) Inflorescência madura, (f) Fruto e ( $g$ ) Corte transversal do fruto. used to estimate the soil coverage, the measuring tape was stretched on the ground, and we observed along two meters if there were plants covering the ground, after the measure was converted to percentage of total coverage.

The hemispherical photographs were taken in each plot, one per $20 \times 20 \mathrm{~m}$ plot, to estimate the CO. A total of 25 photographs were taken altogether using a Sigma $8 \mathrm{~mm}$ fish-eye lens attached to a Nikon D80 camera. The photographs were taken until 10 a.m. to avoid over-0), 1 where the photographs were analyzed.

\subsection{Data analysis}

The mean, standard deviation and coefficient of variation for each ontogenetic stage were calculated in order to describe the population structure and fruit characteristics. We used the Morisita Index of Dispersion (IS) (KREBS, 1999) to analyze the spatial distribution of individuals of different classes. We analyzed the distribution for each ontogenetic stage on an individual basis as well as for the population as a whole.

To calculate the Morisita Index of Dispersion (I $\delta$ ) (KREBS, 1999), we used the Lizaro Morizita Calc software v. 1.0 (RODRIGUES, 2007). The significance of the value of I $\delta$ was tested from the F statistic with $\alpha=0.05$. The distribution pattern was considered random when I $\delta$ equals to one, aggregated was greater than one and uniform when less than one.

The data were tested for normality using the Kolmogorov-Smirnov test. We analysed the relationship between number of leaves and individuals height by performing Spearman's correlation test. We also tested if the number of seedling in each plot was linked to the number of reproducers, declivity, basal area, soil coverage and canopy openness by performing the multiple regression test. Before running the multiple regression test the data were transformed using the square root transformation technique to meet the assumptions of normality as suggested by Bartlett (1936), where $X^{\prime}=\sqrt{X+0.5}$.

\section{RESULTS}

We found 2,328 Attalea phalerata individuals per hectare. 1,248 of these individuals were categorized into seedling stage, 844 were categorized into juvenile stage, 155 were categorized into virgin stage and 81

Revista Árvore, Viçosa-MG, v.36, n.4, p.637-645, 2012 
were categorized into reproducer stage (Table 1$)$. The first two ontogenetic stages accounted for $89.8 \%$ of the total individuals found in the population. In each plot of $400 \mathrm{~m}^{2}$, it was found an average of 3.24 reproducers ( \pm 4.26$), 6.20$ virgins $( \pm 6.50)$, and of $100 \mathrm{~m}^{2}$, an average of 8.44 juveniles $( \pm 6,78)$ and 12.48 seedlings $( \pm 11.20)$.

The Morisita Index of Dispersion (I $\delta$ ) showed values greater than one for each ontogenetic stages and for the population as a whole. These data indicate that the studied population is clustered. A. phalerata fruits production and characteristics were described and the results are shown in Table 2.

We found a significant relationship between the number of leaves and height of individuals ( $S=12,126,419$, $\mathrm{p}<0.0001, \mathrm{r}_{\mathrm{s}}=0.8336$ ) (Fig. 2). Multiple regression model employing number of seedlings as dependent variable and number of reproducers, declivity, basal area, soil coverage and canopy openness as independent variable was not significant $\left(\mathrm{F}_{5,19}=0.698, \mathrm{p}=0.632\right)$, implying that any independent variable affects the seedlings number in studied fragment. The detailed results of the analysis can be seen in Table 3 .

\section{DISCUSSION}

A similar number of individual was found in a study with a population of Attalea speciosa Mart. ex Spreng., in a seasonal swamp forest at the margins of Igarapé Azul. In this study, it was found a total of 2,393 individuals (SCARIOT et al., 1989). In a population of Astrocaryum aculeatum G. Mey. it was found that the first two height class represent $69 \%$ of total individuals, the class between $21-30 \mathrm{~cm}$ was the most common and therefore bearing the greatest number of individuals. The population studied has a $J$ reverse curve for the seedlings and juveniles (NASCIMENTO et al., 1997). A greater number of individuals present in the first class sizes, decreasing toward individuals with larger size are a common pattern in many natural populations (FELFILI, 1997). The high number of individuals in the early classes indicates that successful recruitment is occurring (LIMA et al., 2003).

The cluster distribution was also found by Silva and Tabarelli (2001) for Bactris acanthocarpa Mart. in an Atlantic forest. The same distribution was found

Table 1 - Total and per plot density of Attalea phalerata in a fragment of semideciduous forest in Araguari, MG.

Tabela 1 - Densidade de Attalea phalerata Mart. ex Spreng total e por parcela, em um fragmento de Floresta Semidecidual, em Araguari, $M G$.

\begin{tabular}{lcccc}
\hline Ontogenetic stage & Total density & Mean density per plot & Standard deviation & Coefficient of variation \\
\hline Seedling & 1 & 12.48 & 11.20 & 131.63 \\
Juveniles $^{1}$ & 312 & 8.44 & 6.78 & 104.84 \\
Virgins $^{2}$ & 211 & 6.20 & 6.50 & 80.36 \\
Reproducers $^{2}$ & 155 & 3.24 & 4.26 & 89.74 \\
\hline
\end{tabular}

1 - Sampled in $100 \mathrm{~m}^{2}$ plots, 2 - Sampled in $400 \mathrm{~m}^{2}$ plots.

Table 2 - Number of fruits per bunch, size and weight of the fruit and endocarp and size of the seeds and number of Attalea phalerata in a remnant area of a Tropical Semideciduous Forest, in Araguari, MG.

Tabela 2 - Número de frutos por cacho, tamanho e peso dos frutos e endocarpo e tamanho e número de sementes de Attalea phalerata, em um fragmento de Floresta Tropical Semideciual, em Araguari, $M G$.

\begin{tabular}{|c|c|c|c|c|c|c|c|c|}
\hline \multirow[b]{2}{*}{ Values } & \multirow{2}{*}{$\frac{\text { Bunch }}{\mathrm{N}}$} & \multicolumn{4}{|c|}{ Fruit } & \multicolumn{3}{|c|}{ Seed } \\
\hline & & $\begin{array}{c}\text { LGT } \\
(\mathrm{mm})\end{array}$ & $\begin{array}{c}\text { DIA } \\
(\mathrm{mm})\end{array}$ & $\begin{array}{l}\text { FW } \\
(\mathrm{g})\end{array}$ & $\begin{array}{l}\text { END } \\
(\mathrm{mm})\end{array}$ & $\mathrm{N}$ & $\begin{array}{l}\text { length } \\
(\mathrm{mm})\end{array}$ & $\begin{array}{c}\text { diameter } \\
(\mathrm{mm})\end{array}$ \\
\hline Mean & 127.6 & 62.4 & 33.2 & 41.0 & 5.5 & 2.6 & 29.1 & 8.8 \\
\hline Minimum & 87.0 & 23.7 & 23.1 & 12.0 & 4.0 & 1 & 22.1 & 6.3 \\
\hline Maximum & 163.0 & 77.8 & 48.6 & 71.0 & 7.2 & 4 & 36.9 & 10.9 \\
\hline $\mathrm{SD}$ & 30.8 & 7.4 & 5.0 & 14.1 & 0.8 & 0.9 & 3.8 & 1.0 \\
\hline
\end{tabular}

N: Number; LGT: Length; DIA: Diameter; FW: fresh weight; END: endocarp; and SD: Standard Deviation.

Revista Árvore, Viçosa-MG, v.36, n.4, p.637-645, 2012 
for other six species of palm trees in cerrado sensu stricto and this might be related to some environmental variable rate or predation, dispersal ability, seed germination and seedling establishment (LIMA et al., 2003). The cluster pattern was also observed for Attalea humilis Mart. ex Spreng. This pattern may be mediated by rodents, falling trees (gaps) and fire, that can lead to forest formations dominated by A. humilis (SOUZA; MARTINS, 2002).

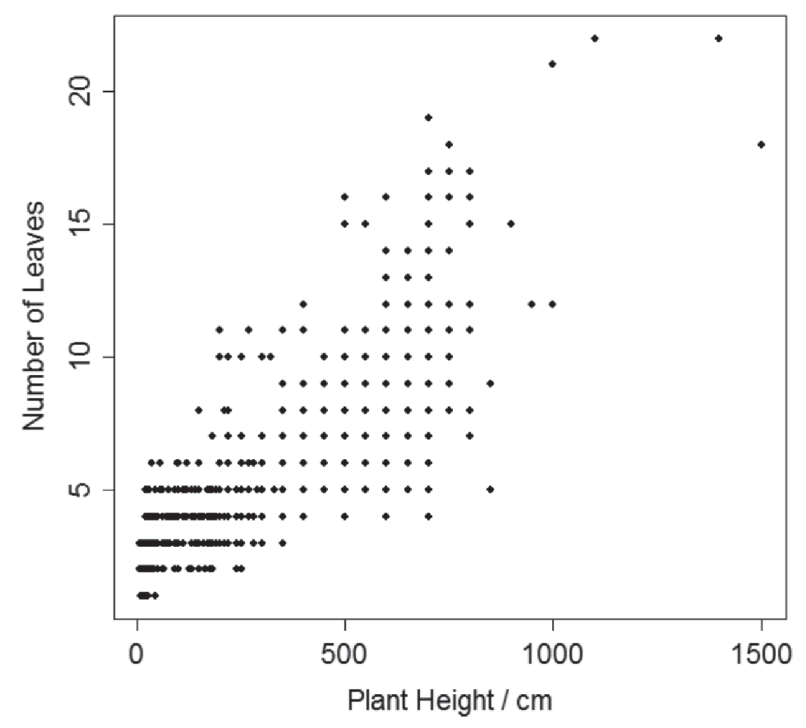

Figure 2 - Relationship among height and number of leaves of a population of Attalea phalerata Mart. ex Spreng in a remnant area of Tropical Semideciduous forest, in Araguari, MG. $(\mathrm{S}=12,126,419, \mathrm{p}<0.0001$, $\left.\mathrm{r}_{\mathrm{s}}=0.8336\right)$.

Figura 2 - Relação entre a altura e número de folhas de uma população de Attalea phalerata Mart. ex Spreng em um fragmento de Floresta Tropical Semidecidual, em Araguari, $M G(S=12,126,419$, $\left.p<0,0001, r_{s}=0,8336\right)$.
Large-seeds palms, such as A. phalerata, have high seed predation rates by bruchid beetles (FRAGOSO et al., 2006: Attalea maripa; SALM 2006: A. maripa; SCARIOT 1998: Acrocomia aculeata), and by rodents (RIBEIRO, et al., 2010). Selective forces, as seed predation, favored multiseeded fruits, such as $A$. phalerata, because each additional seed increases the probability of surviving predation (BRADFORD; SMITH, 1977; SAMPAIO et al., 2010).

A significant relationship between number of leaves and height of individuals was also reported for a population of Euterpe edulis Mart., the change in growth pattern of the species is related to the number of leaves (SILVA, 1991). The relationship between number of leaves and individual height was found in a population of Geonoma schottiana Mart., in the National Park of Brasília (SAMPAIO; SCARIOT, 2008). For Euterpe spp. the number of leaves increases with maturity, and the new leaves are continually formed to replace old ones and this requires a vertical growth (VAN VALEN, 1975). This strong correlation between height and leaf number, suggests a large investment in the production of leaves to capture light and to reach the forest canopy. This characteristic can be expected for a pioneer species, which also can colonize clearings and open areas in the field of Tropical Semideciduous forest.

Also, for A. aculeatum no relationship was found between the amount of reproductive adults in the plots and the number of seedlings, when the author discussed areas with low and high density separately (SALM, 2005). In this study, the relationship between reproductive adults and number of seedlings may not have occurred due to our sampling design. Seedlings were sampled in sub-plots $(10 \times 10 \mathrm{~m})$ in the corner of the plots $(20 \times 20 \mathrm{~m})$, where there were many reproducers the seedlings may were not contained

Table 3 - Detailed results of multiple regression with number of seedlings as variable dependent $\left(\mathrm{F}_{5,19}=0.698, \mathrm{p}=0.632\right)$. Tabela 3 - Resultado detalhado da regressão múltipla com número de plântulas como variável dependente $(F 5,19=0,698$, $p=0,632$ ).

\begin{tabular}{lccccc}
\hline Independent variable & $\mathrm{B}$ & S.E. of $\beta$ & $\mathrm{t}_{19}$ & $\mathrm{p}$ values & Partial correlation \\
\hline Reproducers number & 0.006 & 0.225 & 0.024 & 0.981 & 0.006 \\
Canopy openness & -0.125 & 0.236 & -0.528 & 0.604 & -0.120 \\
Declivity & -0.008 & 0.224 & -0.037 & 0.971 & -0.008 \\
Soil coverage & -0.358 & 0.228 & -1.575 & 0.132 & -0.340 \\
Basal area & 0.186 & 0.232 & 0.802 & 0.433 & 0.181 \\
\hline
\end{tabular}

$\mathrm{b} \beta=$ angular coefficient and S.E. = standard error.

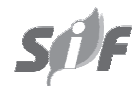

Revista Árvore, Viçosa-MG, v.36, n.4, p.637-645, 2012 
in the sub-plot. In addition, adults may be present in the vicinity of the main plots and contributed to the number of seedlings in sub-plots.

Multiple regression model was not significant. Luminosity should be even more important for species occupying the understory of tropical forests, where light conditions are very restricted (MONTGOMERY, 2004). When studying palms in a seasonal swamp in eastern, Amazon Scariot et al. (1989), found that just one species, A. speciosa, represented $60 \%$ of this individuals and it occurred in great density in less humid areas. The authors suggested that the dominance of this species in the area could be due to high light intensity as a limiting factor, however Oliveira-Filho et al. (1997) reports that in the disturbed forest, the canopy is lower and has greater penetration of light. Since the study area was an anthropized forest, light in the plots did not appear to be a limiting factor for the recruitment of new individuals. The local topography determines declivity and interferes in the pattern of forest architecture (KAHN, 1987). The declivity was the most important variable for seedlings in a gallery forest, and the increase of the slope leading to a reduction in the number of seedlings (MARIMON et al., 2010). In this study, declivity was not correlated with regeneration, probably another factor, such as predation, plays a more important role in regeneration process. This will be further discussed.

In tropical deciduous forest, high herbaceous and shrub covers probably has prevented tree regeneration, regardless to canopy disturbance (VIEIRA; SCARIOT, 2008). The competing vegetation at ground level could be responsible for some regeneration failures (FREDERIKSEN; MOSTACEDO, 2000). In semideciduous forests, we expected this result too; however the result of multiple regression was not significant, showing that soil coverage does not affect regeneration of $A$. phalerata. We probably found this result because the soil cover was small (25.9\%) in the study area when compared to ground cover of $90 \%$ found in another semideciduous forest (MARTINS et al., 2002), and the ground cover of $80 \%$ in a deciduous forest (VIEIRA; SCARIOT, 2008).

Basal area is a convenient indicator of stand density (number of trees ha ${ }^{-1}$ ) (PHILIP, 1994) and a good relationship has been established between it and canopy cover (JENKINS; CHAMBERS, 1989). The effects of the overstorey, as characterized by the basal area, can be summarized as being a negative one on the growth of natural regeneration and a positive one on its initial density (PAGE et al., 2001). For the present study, the natural regeneration was not significantly affected by basal area, suggesting that another factor is acting in the regeneration process. We suggest that predation, an item not evaluated in this study, is acting as an important variable. In the field, we could observe many fruits showing signs of predation by beetles (bruchids).

Predation by bruchids has a negative effect on the viability of palm species seeds. Species like $A$. phalerata, usually overcome a higher mortality rate due to predation by bruchids (QUIROGA-CASTRO; ROLDÁN, 2001). Moreover, dispersion is another factor that was not analyzed, and could also be affecting the regeneration process. In small fragments, dispersion is compromised due to absence of rodents, which in turn, leads to a clustered distribution of individuals (ALMEIDA; GALETTI, 2007) and will determine whether the seed will reach or not propitious patches (JANZEN, 1970).

\section{CONCLUSION}

What are the population structure and density of Attalea phalerata in the studied fragment? The population structure of species presented individuals in all size classes and regular recruitment of new individuals in the population, describing a relatively stable population. The density of A. phalerata and distribution pattern found for the population are probably signs of formation of oligarchic forests in the study area, moreover, the species seems to be able to colonize clearings and open areas. Are there any influences of reproducers presence, canopy openness, declivity, basal area and soil coverage on recruitment of individuals in this population? The multiple regression analysis did not find any significant results, which suggests that none of the analyzed factors were affecting the natural regeneration of Attalea phalerata in the fragment.

\section{ACKNOWLEDGEMENTS}

The authors of this work would like to thank the Fundação de Amparo à Pesquisa do Estado de Minas Gerais (FAPEMIG) and Universidade Federal de Uberlândia (UFU) for the financial and logistic support. 


\section{REFERENCES}

ALMEIDA, L. B.; GALETTI, M. Seed dispersal and spatial distribution of Attalea geraensis (Arecaceae) in two remnants of Cerrado in Southeastern Brazil. Acta Oecologica, v.32, n.1, p.180-187, 2007.

BARTLETT, M. S. The square root transformation in analysis of variance. Supplement to the Journal of the Royal Statistical Society, v.3, p.68-78, 1936.

BRADFORD, D. F.; SMITH, C. C. Seed Predation and Seed Number in Scheelea Palm Fruits. Ecology, v.58, n.3, p. 667-673, 1977.

CINTRA, R.; TERBORGH, J. Forest microspatial heterogeneity and seed and seedling survival of the palm Astrocaryum murumuru and the legume Dipteryx micrantha in an Amazonian forest. Ecotropica, v.6, n.1, p.77-88, 2000.

CLARK, D. A. et al. Edaphic and human effects on landscape-scale distributions of Tropical Rain Forest palms. Ecology, v.76, n.8, p.2581-2594, 1995.

ENGELBRECHT, B. M. J.; HERZ, H. M. Evaluation of different methods to estimate understorey light conditions in tropical forests. Journal of Tropical Ecology, v.17, n.2, p.207-224, 2001.

FELFILI, J. M. Diameter and height distributions in a gallery forest tree community and some of its main species in central Brazil over a six-year period (1985-1991). Revista Brasileira de Botânica, v.20, n.2, p.155-162, 1997.

FRAGOSO, J. M. V.; SILVIUS, K. M.; CORREA, J. A. Long-distance seed dispersal by tapirs increases seed survival and aggregates tropical trees. Ecology, v.84, n.8, p.1998-2006, 2006.

FREDERIKSEN, T. S.; MOSTACEDO, B. Regeneration of timber species following selection logging in a Bolivian tropical dry forest. Forest Ecology and Management, v.131, n.1, p.47-55, 2000.

INOUE, A. et al. Effect of image quality, size and câmera type of forest light environment estimates using digital hemispherical photography. Agricultural and Forest Meteorology v.126, n.1, p.89-97, 2004.
HENDERSON, A.; GALEANO, G.; BERNAL, R. A field guide to the palms of the Americas. Princeton: Princeton University Press, 1995. 363p.

HUTCHINGS, M. J. The structure of plant populations. In: CRAWLEY, M. J. (Ed.). Plant Ecology. Oxford: Blackwell Science, 1997. p.325-358.

JANZEN, D. H. Herbivores and the number of tree species in Tropical Forests. The American Naturalist, v. 104 , n.940, p.501-528, 1970 .

JENKINS, M. W.; CHAMBERS, J. L. Understory light levels in mature hardwood stands after partial oversotry removal. Forest Ecology and Management, v.26, n.4, p.247-256, 1989.

JONCKHEERE, I. et al. Review of methods for in situ leaf area index determination. Part I. Theories, sensors and hemispherical photography.

Agricultural and Forest Meteorology, v.121, n.1, p.19-35, 2004.

KAHN, F. The distribution of palms as a function of local topography in Amazonian terra-firme forests. Experientia, v.43, n.3, p.251-259, 1987.

KREBS, C. J. Ecological methodology. 2.ed. New York: Addison-Wesley Educational Publishers, 1999. 620p.

LIMA, E. et al. Diversidade, estrutura e distribuição espacial de palmeiras em um cerrado sensu scricto no Brasil Central - DF. Revista Brasileira de Botânica, v.26, n.3, p.361-370, 2003.

MARIMON, B. S. et al. Environmental determinants for natural regeneration of gallery forest at the Cerrado/Amazonia boundaries in Brazil. Acta Amazonica, v.40, n.1, p.107-118, 2010.

MARTINS, S. V. et al. Regeneração pós-fogo em um fragmento de floresta estacional semidecidual no município de Viçosa, MG. Ciência Florestal, v.2, n.1, p.11-19, 2002.

MONTGOMERY, R. A. Effects of understory foliage on patterns of light attenuation near the forest floor. Biotropica, v.36, n.1, p.33-39, 2004.

Revista Árvore, Viçosa-MG, v.36, n.4, p.637-645, 2012 
NASCIMENTO, A. R. T.; CORTELETTI, J. M.; ALMEIDA, S. S. Distribuição espacial de sementes e juvenis de Astrocaryum aculeatum G.F.W. Meyer (Arecaceae) em Floresta Amazônica de Terra Firme. In: LISBOA, P. L. B. (Ed.) Caxiuanã. Belém: MPEG, 1997.p.287-296.

ODUM, E. P.; BARRET, G. W. Fundamentos de ecologia. São Paulo: Cengage Learning, 2008. 612p.

OLIVEIRA-FILHO, A. T.; MELLO, J. M.; SCOLFORO, J. R. S. Effects of past disturbance and edges on tree community structure and dynamics within a fragment of tropical semideciduous forest in south-eastern Brazil over a ûve-year period (1987-1992). Plant Ecology, v.131, n.1, p.45-66, 1997.

PAGE, L. M.; CAMERON, A. D.; CLARKE, G. C. Influence of overstorey basal area on density and growth of advance regeneration of Sitka spruce in variably thinned stands. Forest Ecology and Management, v.151, n.1, p.25-35, 2001.

PHILIP, M. S. Measuring trees and Forests. Oxford: CAB International, 1994. 310p.

QUIROGA-CASTRO, V. D.; ROLDÁN, A. I. The fate of Attalea phalerata (Palmae) seeds dispersed to a tapir latrine. Biotropica, v.33, n.3, p.472-477, 2001.

RIBEIRO, L. F.; CONDE, L, O. M.; TABARELLI, M. Predação e remoção de sementes de cinco espécies de palmeiras por Guerlinguet usingrami (Thomas, 1901) em um fragmento urbano de Floresta Atlântica Montana. Revista Árvore, v.34, n.4, p.637-649, 2010.

RICH, P. M. Characterizing plant canopies with hemispherical photographs. Remote Sensing Reviews, v.5, n.1, p.13-29, 1990.

\section{RODRIGUES, W. C. Software Lizaro}

Morisita Calc.v.1.0. 2007.

SALM, R. Arborescent palm seed morphology and seedling distribution. Brazilian Journal of Biology, v.65, n.4, p.711-716, 2005.

SALM, R. Invertebrate and vertebrate seed predation in the Amazonian Palm Attalea maripa. Biotropica, v.38, n.4, p.558-560, 2006.
SAMPAIO, C.; CAMILO-ALVES, P.; MOURÃO, G. M. Palms use a bluffing strategy to avoid seed predation by rats in Brazil. Biotropica, v.42, n.1, p.167-173, 2010.

SAMPAIO, M. B.; SCARIOT, A. Growth and reproduction of the understory palm Geonoma schottiana Mart. in the gallery forest in Central Brazil. Revista Brasileira de Botânica, v.31, n.3, p.433-442, 2008.

SATTLER, D.; LINDNER, A.; MORAWETZ, W. A função da sazonalidade no levantamento estrutural de uma Floresta Montana Tropical no Rio de Janeiro. In: CRONEMBERGER, C.; Viveiros de CASTRO, E. B. (Org.). Ciência e conservação na Serra dos Órgãos. Brasília: Ibama, 2007.p.106-116.

SCARIOT, A. Seed dispersal and predation of the palm Acrocomia aculeata. Principes, v.42, n.1, p.5-8, 1998.

SCARIOT, A.; OLIVEIRA-FILHO, A. T.; LLERAS, E. Species richness, density and distribution of palms in an Eastern Amazonian Seasonally Flooded Forest. Principes, v.33, n.1, p.172-179, 1989.

SILVA, D.M. Estrutura de tamanho e padrão espacial de uma população de Euterpe edulis Mart. (Arecaceae) em Mata Mesófila Semidecídua no Município de Campinas, SP. $60 f$. Mestrado em Biologia Vegetal - Universidade Estadual de Campinas, Campinas, 1991.

SILVA, M. G.; TABARELLI, M. Seed dispersal, plant recruitment and spatial distribution of Bactris acanthocarpa Martius (Arecaceae) in a remnant of Atlantic forest in northeast Brazil. Acta Oecologica, v.22, n.1, p.259-268, 2001.

SILVERTOWN, J.; CHARLESWORTH, D. Introduction to plant population biology. Oxford: Blackwell Publishing, 2001. 347p.

SMIRNOVA, O. V.; PALENOVA, M. M.; KOMAROV, A. S. Ontogeny of different life forms of plants and specific features of age and spatial structure of their populations. Russian Journal of Developmental Biology, v.33, n.1, p.1-10, 2002. 
SOUZA, A. F.; MARTINS, F. R. Palmeiras, fogo e sobrevivência. Ciência Hoje, v.31, n.1, p.72-74, 2002.

SOUZA, A. F.; MARTINS, F. R.; MATOS, D. M. S. Detecting ontogenetic stages of the palm Attalea humilis in fragments of the Brazilian Atlantic forest. Canadian Journal of Botany, v.78, NUMERO, p.1227-1237, 2000.

STEEGE, H. T. Winphot 5: a Programme to analyze Vegetation Indices, Light and Light Quality fromHemisperical Photographs. Tropenbos Guyana Reports 95-2, Tropenbos Guyana Programme, Georgetown Guyana,1997.

SVENNING, J. C. Environmental heterogeneity, recruitment limitation and the mesoscale distribution of palms in a tropical montane rain forest (Maquipucuna, Ecuador). Journal of Tropical Ecology, v.17, n.1, p.97-113, 2001.
SVENNING, J. C. Microhabitat specialization in a species-Rich Palm Community in Amazonian Ecuador. Journal of Ecology, v.87, n.1, p.55$65,1999$.

VAN VALEN, L. Life, death, and energy of a tree. Biotropica, v.7, p. 260-269, 1975.

VIEIRA, D. L. M.; SCARIOT, A. Environmental variables and tree population structures in deciduous forests of Central Brazil with different levels of logging. Brazilian Archives of Biology and Technology, v.51, n.4, p. 419431, 2008.

ZHANG, Y.; CHEN, J. M.; MILLER, J. R. Determining digital hemispherical photograph exposure for leaf area index estimation. Agricultural and Forest Meteorology, v.133, n.1/4, p.166-181, 2005. 
